Theme: Ore mining and treatment

\title{
EVALUATION OF THE EFFECT OF ACID TREATMENT ON WHITE BENTONITE*
}

\begin{abstract}
Clays with high content of smectite are denominated bentonites, and are widely used in industry as, for example, agents for bleaching of vegetable oils, animals and minerals. For this use, the smectite clays are treated with inorganic acid of high concentration at temperatures under boiling point, which provide the bentonite's bleaching power. In the present study, a sample of smectite from Cubati, Paraiba, Brazil, was submitted to treatment under moderate conditions $\left(90^{\circ} \mathrm{C}\right.$, reaction times of $1,6,12,18$ and 24 hours in close reactor, concentration of the aqueous solution of hydrochloric acid $1.5 \mathrm{M}$, acid solution/clay ratio of $1 \mathrm{~g} / 10 \mathrm{~mL}$ ), aiming to reduce impurities, responsible for the color of the clay, without causing significant changes in their structure. Thus, clay can be used in the cosmetics industry and other products with high added value. The treated clay was characterized by scanning electron microscopy (SEM), stereomicroscopy, energy dispersive X-ray detector (EDS) and Xray diffraction (XRD). It was observed a bleaching in samples with time of $12 \mathrm{~h}$ to $18 \mathrm{~h}$. With the DRX was possible to monitor the peak intensity of the clay structure and the sample with 12 hours of treatment was not significantly altered its crystalline structure, maintaining the peak clay at d001. The most pronounced changes in the bleaching occurred within the first 12 hours of acid treatment.
\end{abstract}

Keywords: Clays; Acid treatment; Industrial use.

\footnotetext{
Engineer, MSc, Escola Politécnica da Universidade de São Paulo, São Paulo, SP, Brazil.

Engineer, Escola Politécnica da Universidade de São Paulo, São Paulo, SP, Brazil.

Chemical, Escola Politécnica da Universidade de São Paulo, São Paulo, SP, Brazil.

Engineer, PhD, Escola Politécnica da Universidade de São Paulo, São Paulo, SP, Brazil.

Engineer, PhD, CETMIC, La Plata, Argentina.

Engineer, PhD, Escola Politécnica da Universidade de São Paulo, São Paulo, SP, Brazil.
}

\footnotetext{
* Technical contribution to the $69^{\text {th }}$ ABM International Annual Congress and to the ENEMET, July $21^{\text {st }}-25^{\text {th }}$, 2014, São Paulo, SP, Brazil.
} 


\section{INTRODUCTION}

Bentonite is a rock formed in most part by smectite clay mineral originated generally from volcanic ashes, mostly acid after a chemical alteration provided by devitrification [1].

Bentonites are clays formed by smectite mineral clays which are responsible for chemical - technological properties and by accessory minerals usually inert (mica, quartz, and cristobalite) [2].

Clays are hydrated aluminosilicates of alkali metals and alkaline earth which presents a crystalline structure with lamellar geometry formed by combination of silica tetrahedrons [SiO4]4- and alumina octahedrons [AIO4]5-, attached by oxygen atoms and with exchangeable cations in interplanar space [3].

The white bentonite from Bela Vista, Paraiba, Brazil is a smectite clay with nonpreponderate interlayer cation, presenting white color provided by low iron concentration [4].

Bentonites presents a high grade of colloidal material, good capacities of adsorbing and activation [5].

Among the bentonites for industrial use there are bentonites with high capacity of water adsorption and non-adsorption of water. The sodium interlayer is responsible for the bentonites capacity of adsorption. Those without adsorption capacity usually presents calcium as a preponderant interlamellar cation $[6,7]$.

For some industrial uses the bentonites must be clean of mineral impurities. Acid attack provides an increase at specific area by disorganizing the crystalline structure, the mesopores formation and cleaning the mineral impurities. Other benefit of acid attack is the improving of acid sites with more porosity, excellent properties when applied in catalysis [8].

The industrial use for clays is also based on cation exchange capacity and clay minerals properties [9].

Among the clays to industrial use, several groups have been studied aiming a preparation of bleaching clays, using acid attack with high concentration and temperatures near boiling point [10].

The industrial application of bentonites is vast. In oil industry, mostly used as drilling fluids additives; in pharmaceutics and cosmetics as dissecant; in the food industry as oil bleaching, among others applications [11-14].

Bentonites, when activated, are used in bleaching process for oil, organic and mineral, grease and animal fat [15].

The methodology of purifying clays used in this work with mild acid attack is a good alternative for production of clays with more light colors. The economic advantages obtained using Brazilian bentonites over imported clays are a good alternative to obtain materials for use in cosmetic and clay/polymer nanocomposites.

\section{MATERIAL AND METHODS}

\subsection{Start Materials}

The white bentonite clay, in its natural form, was from Cubati, Paraíba's State, Brazil. White bentonite, passing sieve 200 mesh, was submitted to mild acid attack using a concentration of the aqueous solution of hydrochloric acid $1.5 \mathrm{M}$, clay/acid solution

\footnotetext{
* Technical contribution to the $69^{\text {th }}$ ABM International Annual Congress and to the ENEMET, July $21^{\text {st }}-25^{\text {th }}$, 2014, São Paulo, SP, Brazil.
} 


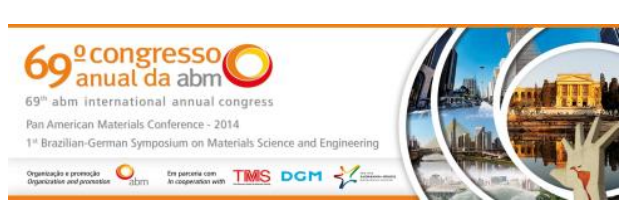

ratio of $1 \mathrm{~g} / 10 \mathrm{~mL}$, at $90^{\circ} \mathrm{C}$ under bellow boiling temperature and at times of reaction of $1,6,12,18$ and 24 hours in close reactor.

After filtered and washed with water until $\mathrm{pH} \mathrm{5-6}$ the clay was dried at $60^{\circ} \mathrm{C}$ and grounded using a manual mortar and vibratory ball mill until completely pass through \#200 mesh sieve.

\subsection{Materials Characterization}

The starting material was characterized by scanning electron microscopy, EDAX INSPECT 50 with energy dispersive $\mathrm{x}$-ray detector (EDS) and X-ray diffraction (XRD).

To observe the clay was used a stereomicroscope Zeiss, model Stemi 2000C.

The XRD was performed on diffractometer model X'Pert Pro MPD (Panalytical) with $\mathrm{Cu}$ anode; scan from $2^{\circ}$ to $90^{\circ} 2 \theta ; 40 \mathrm{kV}$ and $35 \mathrm{~mA}$.

\section{RESULTS AND DISCUSSION}

Figure 1 shows the X-ray diffraction curves of White Bentonite Cubati submitted only to $\mathrm{H} 20$ for $24 \mathrm{~h}$ at $90^{\circ} \mathrm{C}$, we observe the $\mathrm{d}(001)$ characteristic smectitic peak at $14,6 \AA$ with intensity of 120 counts. As impurity the sample presents quartz with a peak at $3,3 \mathrm{~A}$ and an intensity of 200 counts. There are also a kaolinite peak with an intensity of 100 counts.

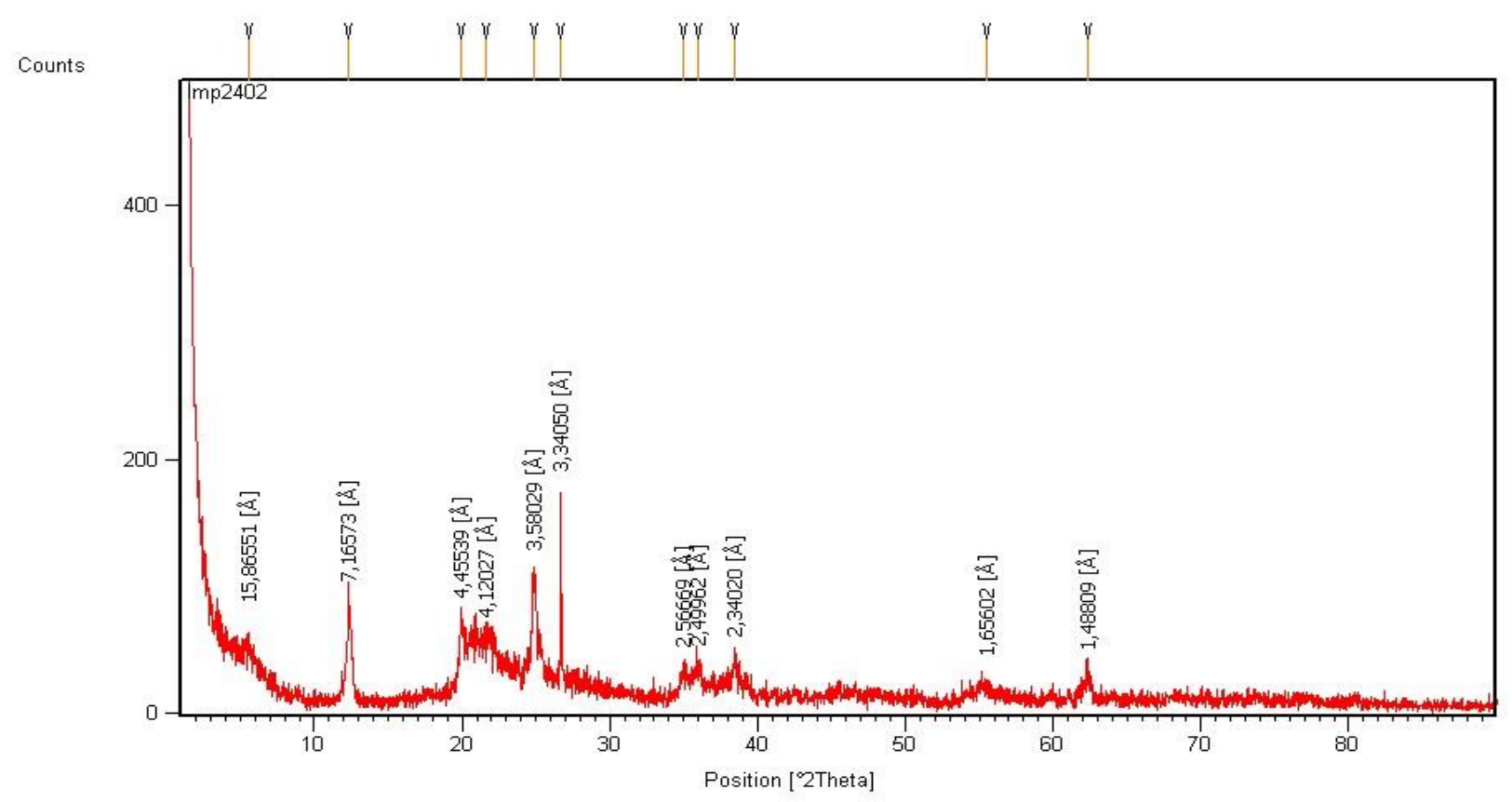

Figure 1 - XRD curve of White Bentonite Cubati $\mathrm{H}_{2} \mathrm{O} 24 \mathrm{~h}$ at $90^{\circ} \mathrm{C}$.

Figure 2 shows the XRD curve of White Bentonite Cubati submitted to mild acid attack during $6 \mathrm{~h}$ at $90^{\circ} \mathrm{C}$. The $\mathrm{d}(001)$ smectitic peak is present at $14,73 \AA$ with an intensity of 120 counts. The quartz, with peak at $3,33 \AA$ presents intensity of 55 counts.

\footnotetext{
* Technical contribution to the $69^{\text {th }}$ ABM International Annual Congress and to the ENEMET, July $21^{\text {st }}-25^{\text {th }}$, 2014, São Paulo, SP, Brazil.
} 


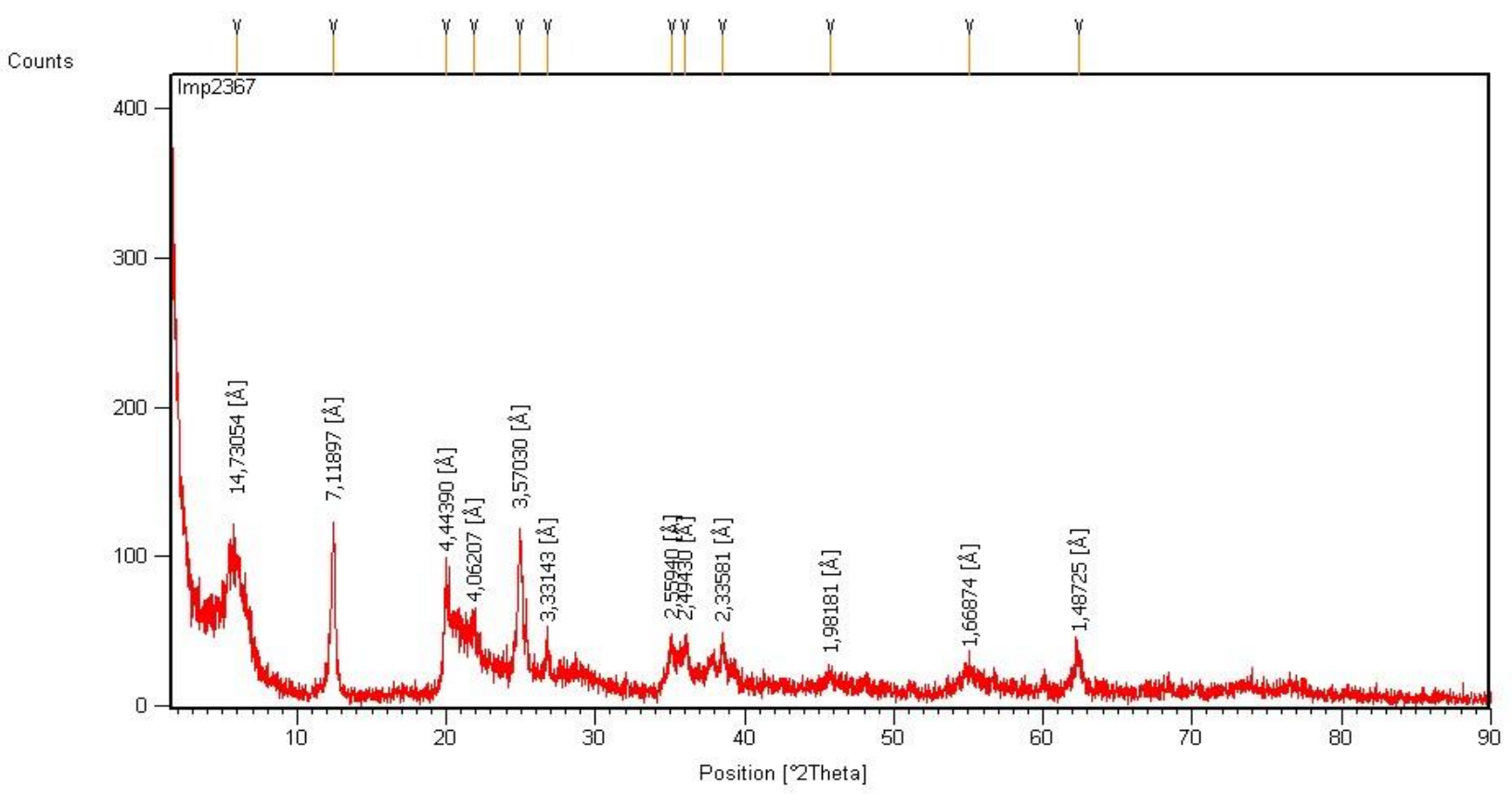

Figure 2 - XRD curve of the White Bentonite Cubati $\mathrm{HCL} 6 \mathrm{~h}$ at $90^{\circ} \mathrm{C}$.

Figure 3 shows the XRD curve of White Bentonite Cubati submitted to mild acid attack during $18 \mathrm{~h}$ at $90^{\circ} \mathrm{C}$. The $\mathrm{d}(001)$ smectitic peak is present at $15,17 \AA$ with an intensity of 90 counts. The quartz, with peak at $3,33 \AA$ presents intensity of 45 counts.

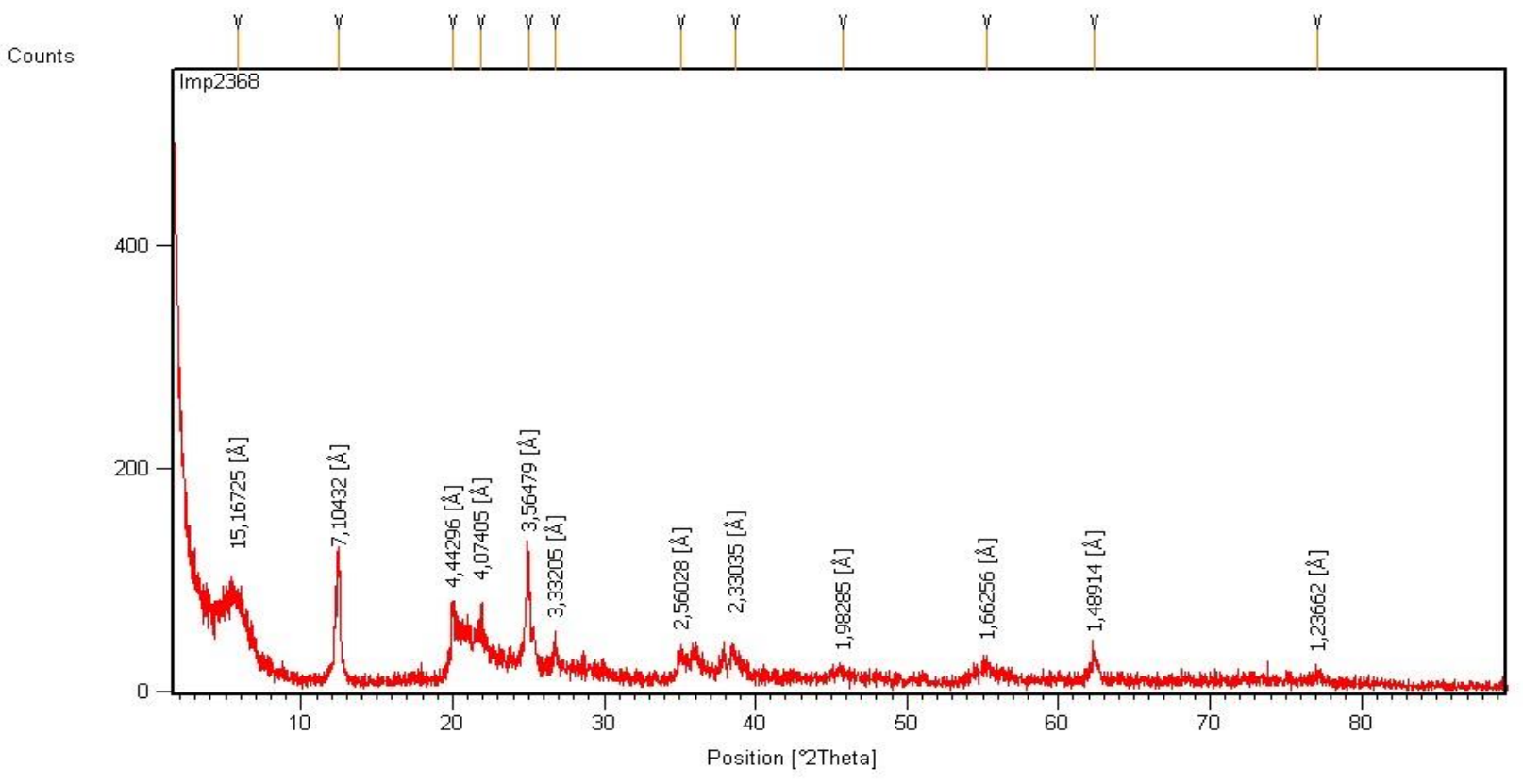

Figure 3 - XRD curve of the White Bentonite Cubati HCL $18 \mathrm{~h}$ at $90^{\circ} \mathrm{C}$.

Table 1 presents the results of $d(001)$ smectitic peaks, smectitic peaks intensities, and intensities of the quartz peaks for the samples of white bentonite Cubati attacked at different times.

\footnotetext{
* Technical contribution to the $69^{\text {th }}$ ABM International Annual Congress and to the ENEMET, July $21^{\text {st }}-25^{\text {th }}$, 2014, São Paulo, SP, Brazil.
} 


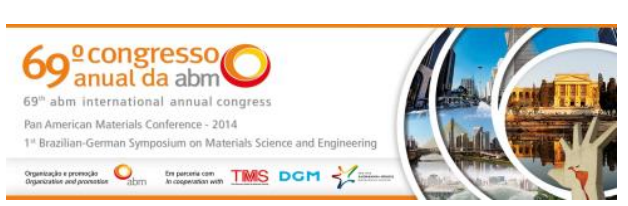

Table 1. $d(001)$ smectitic peaks, smectitic peaks intensities, and intensities of the quartz peaks.

\begin{tabular}{lccc}
\hline Sample & $\begin{array}{c}\text { Smectitic d001 } \\
\text { peak }(\AA)\end{array}$ & $\begin{array}{c}\text { Smectitic peak } \\
\text { intensity. } \\
\text { (counts) }\end{array}$ & $\begin{array}{c}\text { Quartz peak at } \\
3,33 \AA \text { intensity } \\
\text { (counts) }\end{array}$ \\
\hline 24h in water & 14,73 & 65 & 55 \\
\hline 1h attack & 15,45 & 140 & 50 \\
\hline 6h attack & 14,73 & 120 & 55 \\
\hline 12h attack & 15,12 & 90 & 55 \\
\hline 18h attack & 15,16 & 90 & 45 \\
\hline 24h attack & 15,2 & 85 & 45 \\
\hline
\end{tabular}

The sample treated with water only presented a breakdown of the stacking order of layers with the lowest value of peak intensity. The intensity of the smectitic $d(001)$ peak of the acid attack samples tend to diminish its intensity with the time of attack as the acid have more time to destroy the octahedral sheet of the clay mineral. The quartz peak intensity only diminish for the samples attacked for more than 12 hours. The results of energy dispersive X-ray detector (EDS) of white bentonite Cubati are mostly the same, observing in all samples the presence of $\mathrm{Si}, \mathrm{Al}$ and $\mathrm{O}$.

Figure 4 shows the EDS curves of White Bentonite Cubati submitted only to $\mathrm{H}_{2} \mathrm{O}$ for $24 \mathrm{~h}$ at $90^{\circ} \mathrm{C}$.

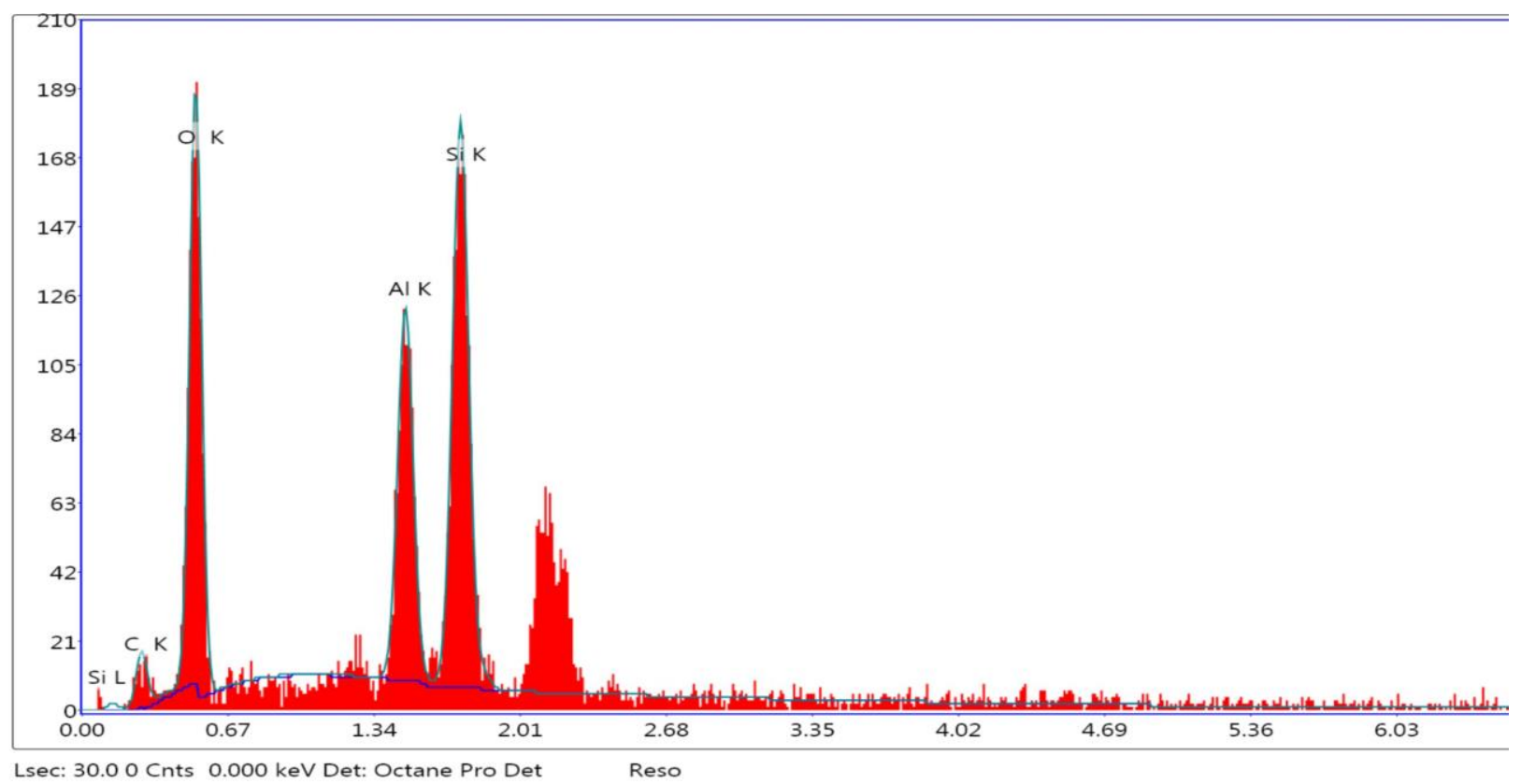

Figure 4 - EDS curve of White Bentonite Cubati $\mathrm{H}_{2} \mathrm{O} 24 \mathrm{~h}$ at $90^{\circ} \mathrm{C}$.

Figure 5 shows the EDS curves of White Bentonite Cubati submitted to $\mathrm{HCl}$ for $6 \mathrm{~h}$ at $90^{\circ} \mathrm{C}$

\footnotetext{
* Technical contribution to the 69th ABM International Annual Congress and to the ENEMET, July $21^{\text {st }}-25^{\text {th }}, 2014$, São Paulo, SP, Brazil.
} 


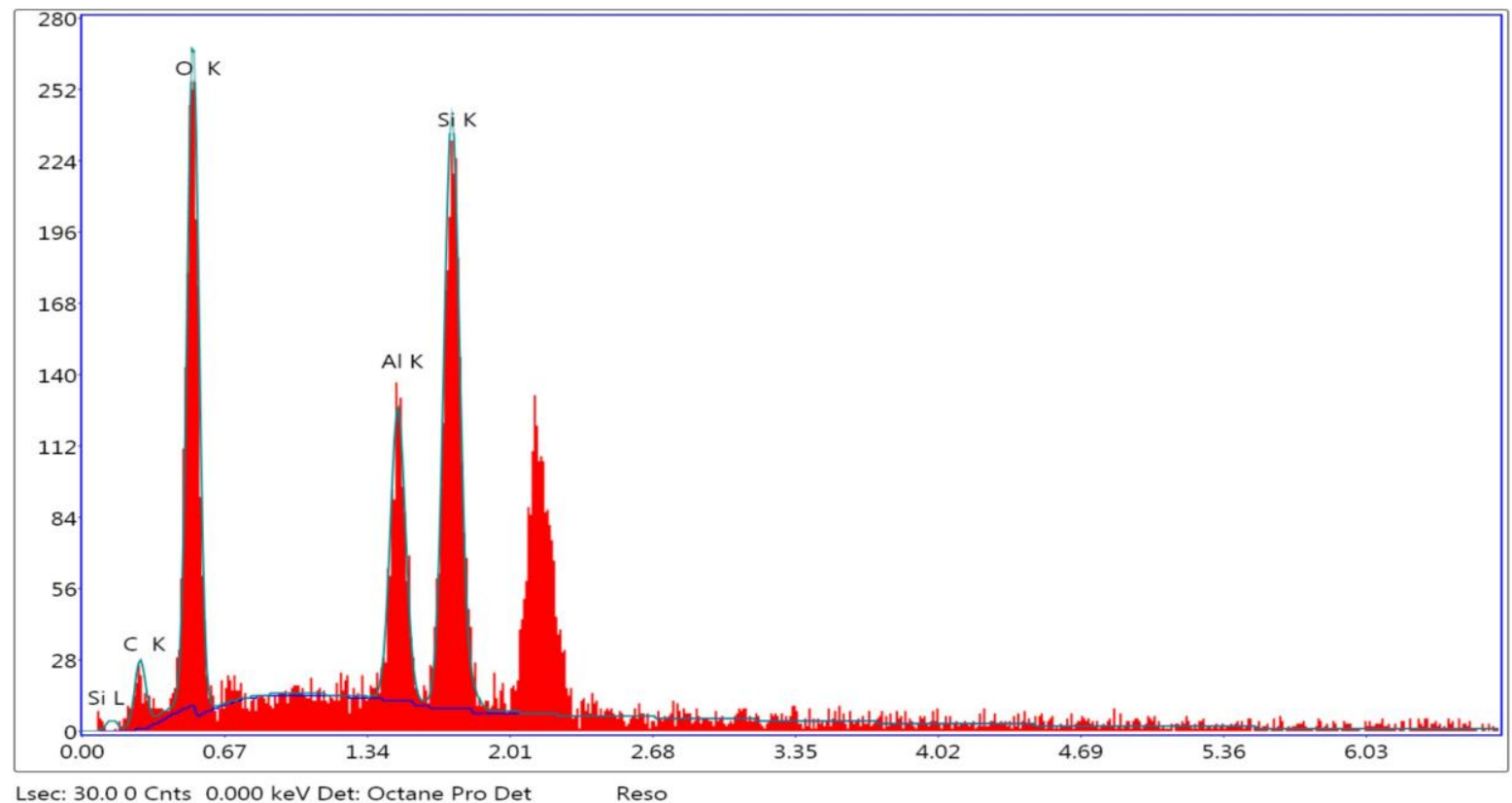

Figure 5 - EDS curve of White Bentonite Cubati $\mathrm{HCL} 6 \mathrm{~h}$ at $90^{\circ} \mathrm{C}$.

The images generated by scanning electron microscopy produced the figures 6 to 9 were is possible to observe in the images of white bentonite Cubati sample submitted to treatment in different times the preservation of the lamellar morphology. The sample attacked for $18 \mathrm{~h}$ shows a more open structure with less quantity of small particles, possible dissolved by the acid.

Figure 6 shows the MEV image of White Bentonite Cubati submitted only to $\mathrm{H} 2 \mathrm{O}$ for $24 \mathrm{~h}$ at $90^{\circ} \mathrm{C}$.

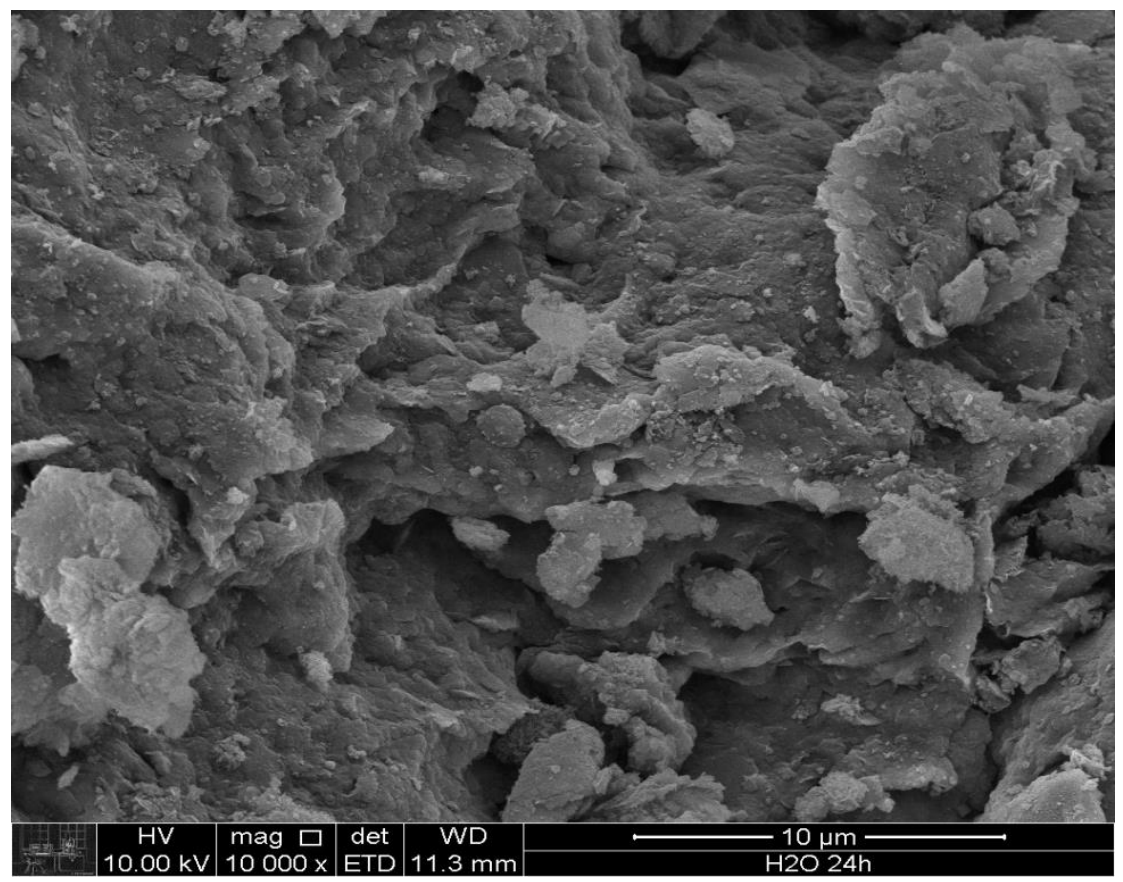

Figure 6 - MEV image of the White Bentonite Cubati $\mathrm{H}_{2} \mathrm{O} 24 \mathrm{~h}$ at $90^{\circ} \mathrm{C}$.

Figure 7 shows the MEV image of White Bentonite Cubati submitted to mild acid attack during $1 \mathrm{~h}$ at $90^{\circ} \mathrm{C}$.

* Technical contribution to the $69^{\text {th }}$ ABM International Annual Congress and to the ENEMET, July $21^{\text {st }}-25^{\text {th }}$, 2014, São Paulo, SP, Brazil. 


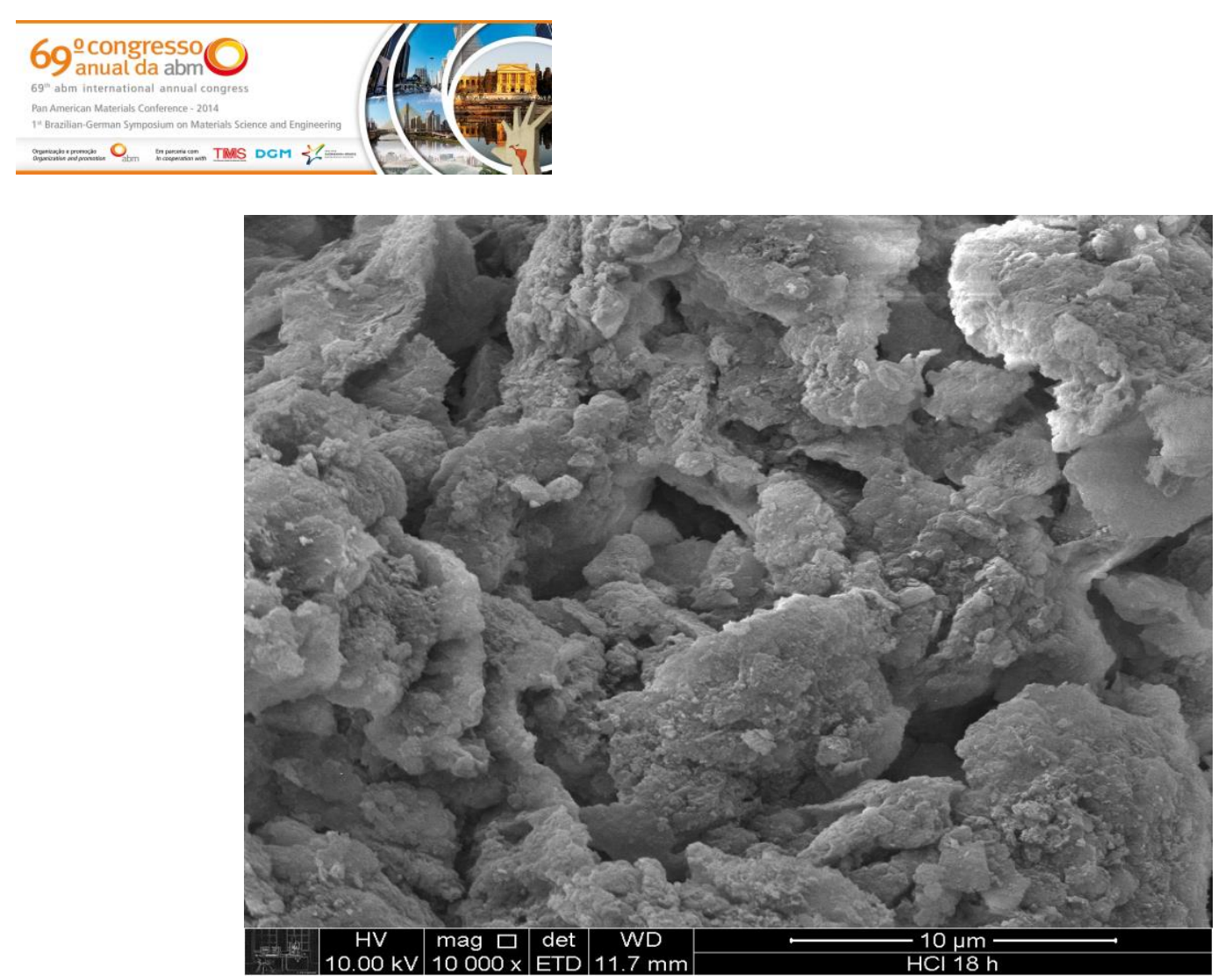

Figure 9 - MEV image of the White Bentonite Cubati $\mathrm{HCl} 18 \mathrm{~h}$ at $90^{\circ} \mathrm{C}$.

The attacked samples presented an increase in color reduction with time of acid attack. Figure 10 shows a stereomicroscopy image of Cubati sample treated with water for $24 \mathrm{~h}$. It is possible to observe some impurities in the sample.

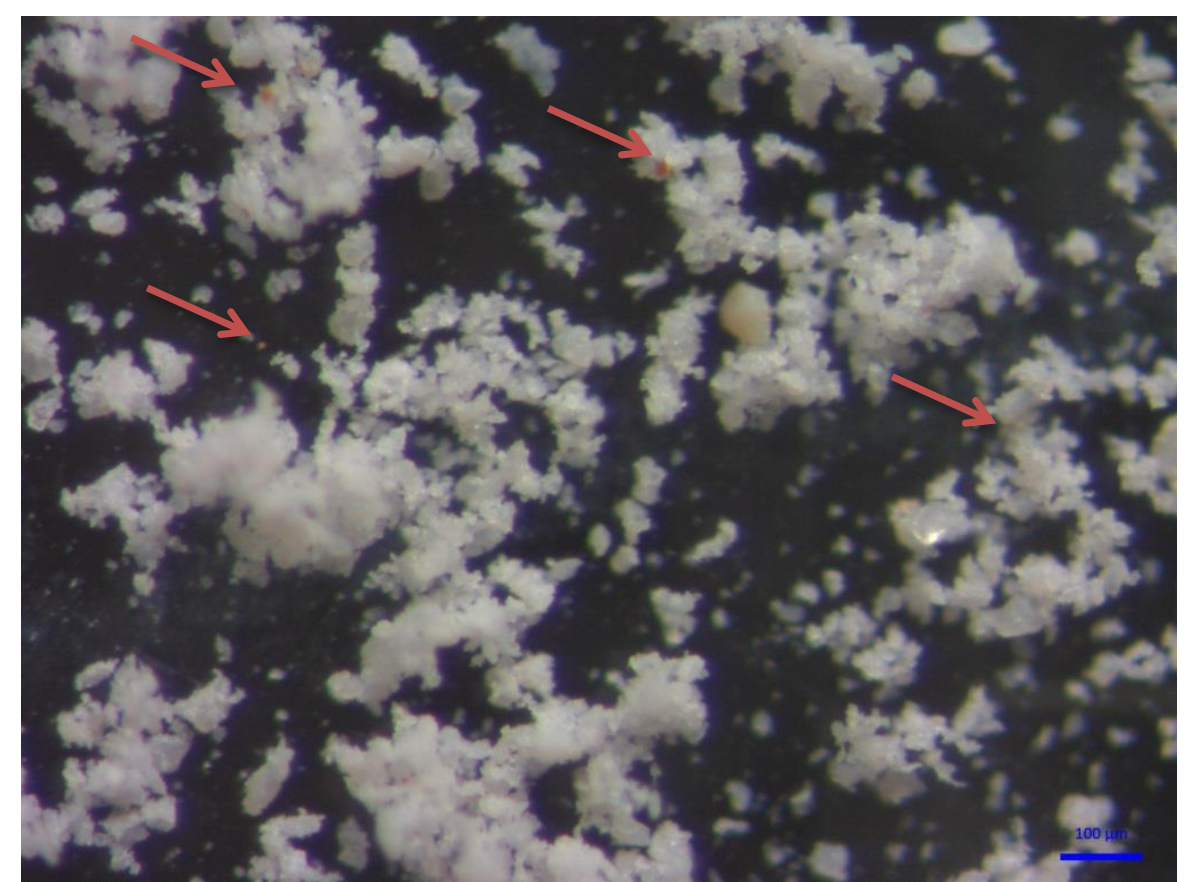

Figure 10 - Image of Cubati- treated with water for $24 \mathrm{~h} .1 \mathrm{~cm}$ corresponds to 1.3 micron.

In Figure 11 is possible to observe a decrease of impurities in the sample submitted to mild attack for $24 \mathrm{~h}$. Samples with attack times from 12 to $24 \mathrm{~h}$ showed a continuous but small decrease of impurities (that is lighter colors) compared with the sample attacked by 6 hours.

* Technical contribution to the 69th $A B M$ International Annual Congress and to the ENEMET, July $21^{\text {st }}-25^{\text {th }}$, 2014, São Paulo, SP, Brazil. 

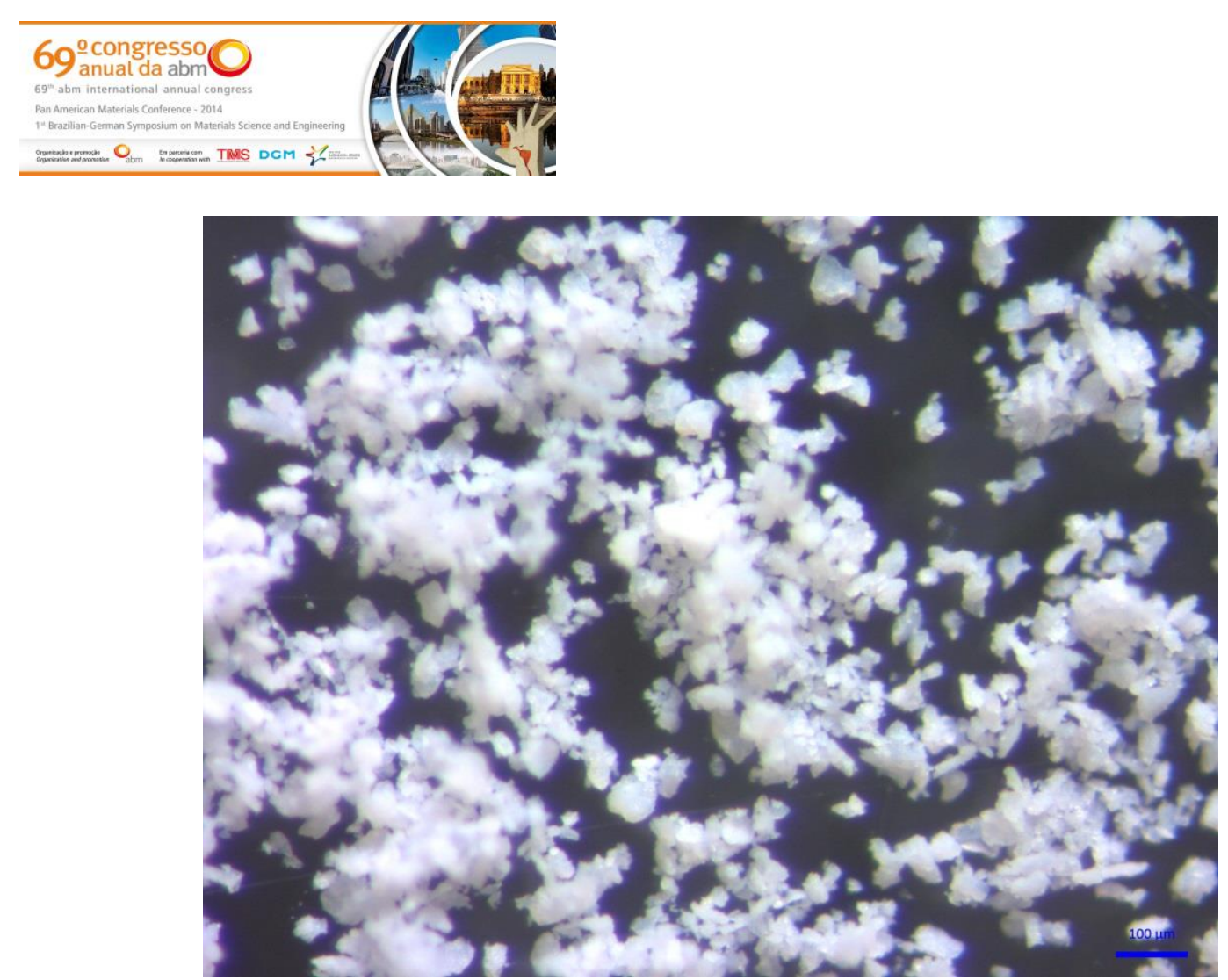

Figure 11 - Image of Cubati- treated with $\mathrm{HCl}$ for $24 \mathrm{~h} .1 \mathrm{~cm}$ corresponds to 1.3 micron.

\section{CONCLUSION}

The sample of white bentonite from Cubati submitted to mild acid attack demonstrated a good response to the purification at reaction times of 6 hours. The crystalline structure of the mineral clay do not presented a significantly destruction otherwise, presented a significant bleaching.

In accordance with the methodology presented and from the results obtained, the objective to decrease the concentration of impurities that provides color, with no great change in the clay minerals structure, permits use the activated clay in products of high value, demonstrating an efficient option, more economical and less aggressive to the environment.

\section{REFERENCES}

1 Ross CS, Shannon EV. Minerals of bentonite and realted clays and their physical properties. J. American Ceramic Socity, 1926; 9 (77).

2 Valenzuela-Diaz FR. Preparação a nível de laboratório de algumas argilas esmectíticas organofílicas. Tese (Doutorado). Departamento de Engenharia Química da Escola Politécnica da Universidade de São Paulo, SP, 1994.

3 Breck DW. Zeolitic Molecular Sieves, New York, Wiley, 1974.

4 Valenzuela-Díaz RF, Santos PS, Santos HS. A Importância das argilas industriais brasileiras. Química Industrial V.42 p.33-37, 1992.

5 Abreu SF. Recursos minerais do Brasil, Ed. Edgard Blucher, 2ª Ed., V.1, São Paulo, SP, 324p, 1973.

6 Pereira KRO. Ativação ácida e preparação de argilas organofílicas partindo-se de argila esmectítica proveniente do Estado da Paraíba. Dissertação (Mestrado), Orientadora: Meiry Gláucia Freire Rodrigues, Campina Grande - PB, 2003.

7 Pereira KRO, Vianna MMGR; Rodrigues MG, Valenzuela-Diaz FR. Argila de alguns poluentes orgânicos em argilas organofílicas. Anais do XVI Congresso Brasileiro de Ciência e Engenharia dos Materiais, CD. Porto Alegre, RS 2004.

8 Vaccari, A.; Applied Clay Science 14, 1999

\footnotetext{
* Technical contribution to the $69^{\text {th }} A B M$ International Annual Congress and to the ENEMET, July $21^{\text {st }}-25^{\text {th }}$, 2014, São Paulo, SP, Brazil.
} 
9 Grim RE. Bentonites - Elsevier, Amsterdam, 1978.

10 Santos PS. Ciência e Tecnologia de Argilas 2a com a colaboração de Soza Santos H, V. 3 ed., Edgar Blücher, S. Paulo, SP (1989)vol.1 e 1992 vol.2e3 1ed. Tecnologia das Argilas - vol.2 Edgar Blücher e EDUSP, São Paulo, SP, 1974.

11 Gomes,C.F.Argilas: o que são e para que servem, 1a Ed., Fundação Calouste Gulbenkian, Lisboa, Portugal Ed., Fundação Calouste Gulbenkian, Lisboa, Portugal (1988) 160.

12 Ferreira HS, Menezes RR, Martins AB, Neves GA, Ferreira HC. Cerâmica. 2008;54:77.

13 Amorim LV, Farias KV, Viana JD, Barbosa MIR, Pereira E, França KB, et al. Cerâmica. 2005;51:128.

14 Pereira KRO, Hanna RA, Vianna MMGR, Pinto CA, Rodrigues MG, Valenzuela-Diaz FR. Brazilian organoclays as nanostructure sorbents of petroleum-derived hydrocarbons. Materials Research, 2005; 8(1): 77-80.

15 Valenzuela-Diaz FR, Santos PS. Studies on the acid ativation of Brasilian smetctitic clays. Química Nova, 2001; 24(3). 